\title{
SUPPLIERS RANKING IN PRODUCTION SYSTEMS BY FUZZY TOPSIS METHOD, CASE STUDY: UNDERGROUND COAL MINES RESAVICA- SERBIA
}

\author{
Goran Stojanović ${ }^{1}$, Dejan Bogdanović
}

Received: May 16, 2021

Accepted: June 02, 2021

\begin{abstract}
Selection and evaluation of suppliers is a complex issue that depends mostly on the quality of the decision-making process. The aim of this paper is to point to the possibility of applying multi-criteria analysis (Fuzzy TOPSIS method) for the selection of suppliers operating in mining systems in the case of the Public Company for Underground Coal Mining Resavica (JPPEU Resavica) -Serbia. Ranking of companies is done based on ten criteria, and it has considered a list of five suppliers (Supplier 1; Supplier 2; Supplier 3; Supplier 4; Supplier 5). The criteria cover the most important aspects of suppliers' selection such as: management and organization, quality, technical ability, production facilities and capacity, financial position, delivery, service, relationship-connectivity, security and environmental protection and price. In doing so, it has used the experts knowledge from JPPEU Resavica to determine the significance and impact of certain criteria to the process of supplier selection and evaluation of suppliers in regard to each criterion. Fuzzy TOPSIS method was used for determining the final ranking of suppliers. The supplier with the top rank was the Supplier 4. The obtained results indicate that the proposed method gives excellent results and can be used for solving various, and the most complex problems that occur in mining systems, as well as in other production systems.
\end{abstract}

Keywords: Supplier Selection, Mining Systems, Multi-Criteria Analysis, Fuzzy TOPSIS, Ranking

\section{INTRODUCTION}

As far back as 1943. Lewis suggested that the selection of appropriate suppliers is the most important thing from all liability in connection with the procurement. Therefore, all companies try to build long-term and profitable relationships with suppliers (Lewis, 1943).

Nowadays, the selection of suppliers is one of the most important functions that must be performed by the decision-makers in order to establish long-term viability of the

\footnotetext{
${ }^{1}$ University "Union-Nikola Tesla" Belgrade - Faculty of applied sciences, Nis, Republic of Serbia

${ }^{2}$ University of Belgrade - Technical Faculty in Bor, Niš, Republic of Serbia

E-mails: stojanovicg11@yahoo.com; dbogdanovic@tfbor.bg.ac.rs
} 
company. Reducing costs, without reducing the overall quality of products or services, would directly affect the overall corporate competitiveness, making the selection and reliability of suppliers the main factor in the production and logistics regime across a wide range of industrial sectors. Reliability of suppliers is a key determinant of competitiveness of the manufacturer. Reliability the supplier is expressed by its fulfillment of customer requirements, which can be measured by the percentage of the quantity of delivery at a given time interval. A perfectly reliable supplier absolutely responses to customer requirements, while an unreliable supplier does not fully comply with customer requirements.

By recent research, it has been concluded that "across the industry, the reliability of suppliers is seen more significantly than the cost" (Erhardt et al., 2010).

The correct selection of suppliers is one of the key tasks in the supply chain for each production system and includes the involvement of various statistical techniques for processing and data analysis, as well as support for the decision making i.e. ranking of possible options, which is reflected in the application of multicriteria methods for decision making (Wu and Olson, 2008).

As companies endeavor to achieve and maintain a competitive advantage through the system of plan and business, they also aim to create optimized supply chains. The supply chain consists of a complex series of stages, starting from stocks of raw materials, manufacture parts, components and assembly of the final product, to delivery of finished products (Medini, 2015).

In the context of supply chain management, supplier selection is considered as one of the key decisions for the managers. The strategic role in the supply chain will take the supplier that can follow the changes in innovation i.e. in the design phase of new products (Croom, 2001).

The selection of suppliers and management can be applied to different suppliers during the product's life cycle from raw material acquisition to the end of its life (Bai and Sarkis, 2010). Also, relationships among nodes in supply chain network is very dynamic (Ahn and Hur, 2016). To ensure uninterrupted supply of products, it is necessary to consider more than one supplier for each product (Stojanović, 2016).

The process of selection of suppliers for most of the procurement can be observed through the following stages: defining the need for a new supplier, establishing criteria for decision-making, drawing up the shortlist of potential suppliers, the final selection of suppliers and continuous monitoring, assessment and evaluation of selected suppliers. Periodically evaluating the reliability of suppliers is carried out with the key aim of security standards of product quality, product quantity, delivery time and all with the selection of the right source at the right time and at the best price. With the growing needs of production companies to introduce into their management systems the quality management function at the right time (Just In Time - JIT), the decision on the selection 
of supplier has become even more important (Muralidharan et al., 2002). The introduction of a new trend at the right time (JIT) production philosophy put the emphasis on establishing long-term relationships with a smaller but better supplier (Vokurka et al., 1996; Talluri and Narasimhan, 2004; Prahinski et al., 2004).

Therefore, proper and appropriate selection of suppliers is a very important factor for the future of the organization, because in many ways can reduce operating costs and improve the quality of their final product (Zeydan et al.,2011). Today, however, in the highly competitive work environment, low cost and, high quality products without satisfactory suppliers cannot be achieved (Vokurka et al., 1996). Also, through a good selection of suppliers it is possible to establish a strategic relationship with suppliers for the acquisition of competitive advantages and improving organizational characteristics (Lima et al., 2013). This long-term expectation developed between manufacturers and suppliers may provide an opportunity for significant performance improvement of organization (Choy et al., 2002). Research has recently come to the conclusion that "the reliability of suppliers across the industry is considered more important than the cost" (Erhardt et al., 2010).

The main objective of this paper is to solve above mentioned problem by fuzzy TOPSIS method and expert knowledge, as well as to present efficient way to improve the quality of decisions related to the process of prioritization of reliable suppliers in mining systems. In this connection, the subject of research focuses on the analysis of priority (ranking) the reliability of suppliers in the company JPPEU Resavica- Resavica.

The procedure based on a multicriteria ranking method can serve as a good basis for solving the problems in questions because it allows obtaining the list of priorities, based on the ranking in relation to the multiple criteria at the same time. Also, the results of this analysis may represent a baseline for further optimization models. Certainly, for proper and efficient assessment, the decision maker must have at its disposal a large amount of relevant data to be analyzed.

Modern approach observes the process of forming and optimization of model as a method for decision making with a finite number of alternatives, which are assessed in relation to the many different and conflicting criteria. There are many studies in this area that point to different methods for the selection of suppliers in different contexts (Mafakheri et al.,2011; Vanteddu et al., 2011; Lin, 2012; Ekici, 2013; Qian, 2014).

These methods can simultaneously consider both financial and non-financial factors in the selection procedure. The best known of these methods are models of evaluation, analytic hierarchy process - AHP, analytic network process - ANP, TOPSIS, and PROMETHEE. 


\section{OVERVIEW OF THE PREVIOUS RESEARCH FOR THE PRORIZATION OF THE SUPPLIER RELIABILITY}

In literature and various studies, the selection of suppliers is an area that has emerged as early as the 1960s in supply chains. For many years, the traditional approach of selection of supplier was solely based on the price. However, during the time, the companies realized that the price is no longer an exclusive criteria. After that, they have adopted a more comprehensive multi-criteria approach. In order to properly select a set of suppliers that can positively affect the strategic capability of the organization (Lee et al., 2014) and ensure continuous improvement of customer satisfaction ( $\mathrm{Li}$ and Fun, 1997) there is a need to find new and better ways to select and evaluate suppliers. Also, performance measurement depends on qualitative and quantitative factors. Such factors include the supplier's offered price, delivery time, quality of the item, supplier capacity to flexibly respond to the company's requirements and the geographical position of the supplier (Ekici, 2013). They also include warranties, production capacity, technical capabilities, the ability to manage, the reputation of the seller, the financial position, the labor relations and services (Kar and Pani, 2014).

For the majority of procurements, the selection of suppliers as a process can be considered through the following phases: defining the need for a new supplier, setting criteria for decision making, making a narrowed down selection of potential suppliers, final selection of suppliers, and continuous monitoring, evaluation and evaluation of selected suppliers.

Earlier supplier selection studies were focused on identifying the criteria used for selection of supplier. Decisions on the selection of suppliers are made complex by the fact that different, often conflicting criteria must be taken into account in the decisionmaking process.

In a study that became the reference for most of the supplier selection papers, (Dickson, 1966) identified 23 attributes (among which the most important are: quality, timely delivery, best performance) that managers need to consider in selection of supplier process.

According to Lehmann and O'Shaughnessy (Lehmann and O'Shaughnessy, 1974), the key criteria for supplier selection were: price, delivery, reliability and reputation of the supplier. Furthermore, Evans suggested price, quality and delivery as a key criteria for assessing suppliers in the industrial market (Evans, 1980). Also, Shipley suggested that the selection of suppliers include three criteria: quality, price and delivery time (Shipley, 1985).

Ellram suggested that in the process of selecting suppliers, companies must consider whether product quality, price offer, delivery time, and the overall quality of services meet organizational requirements. According to his work, most researchers focus more 
on quantitative criteria (Ellram, 1990). For this reason, in his paper, he tried to diminish the importance of quantitative criteria and to give priority to new qualitative criteria that should have a greater impact on long-term cooperation between the company and suppliers. These new favorable qualitative criteria were divided into four groups:

1) Financial aspects (economic performances, financial stability),

2) Organizational culture and strategic issues (trust, leadership, strategic plans, management capability, supplier's organizational structure and staff),

3) Technological issues (assessment of current production capabilities and capacities, supplier's speed of development, supplier's design possibilities, assessment of future production capacities),

4) Other factors (occupational safety and security, supplier's clients, business references).

During the 1990s, many manufacturers were trying to develop strategic alliances with suppliers in order to improve their management of preferences (Shin et al.,2000; Kumar et al., 2006; Verma and Pullman, 1998; Weber et al., 1991). Based on 74 texts published between 1966 and 1990 they have concluded and proposed a set of criteria for selection and measurement of supplier performance, such as: price, delivery, quality, productive capabilities, location, technical capability, reputation, industry position, financial stability, performance history, and maintenance.

According to the study (Birch, 2001), the relationship between the buyer and the supplier must first be defined, and after that the priority assessment criteria should be defined. Birch classifies the criteria into five groups: costs, logistics, quality, development and management.

According to a study (Celebi and Bayraktar, 2008) the same criteria were confirmed as by the research that carried out (Birch, 2001), with the exception that their approach is more integrated in the assessment of suppliers. According to them, categorized factors that equally contain quantitative and qualitative criteria are: logistics, technology, business and business cooperation. It is also one of the first models that adequately distinguishes between the criteria based on their form, depending on whether they are material or non-material.

Chen with the associates have accepted the access to the decision-making phase to solve the problem of selecting suppliers in the supply chain system based on the consideration of five criteria: profitability of suppliers, relationships of connectivity, technological capability, quality of compliance, and conflict resolution (Chen et al., 2006).

According to Lin and Chang, communication, reputation, industry position, connectivity, client responsibility, and conflict resolution are important criteria in the selection of suppliers (Lin and Chang, 2008). 
The concept of importance of organizational size in the process of supplier selection has been investigated by (Wang et al., 2009).

According to Miemczyk et al. (2012), the aim of supplier selection process is to select the best supplier for a particular item, which is reliable, with fair terms, low risk and has the maximum effect for the client. Therefore, the quality of selected suppliers depends on the quality of the selection process (Mendoza et al., 2008). So, it is necessary to use structured methods for selecting suppliers that adequately meet the requirements of the organization.

In literature, a number of studies and eminent authors are dealing with the issue of supplier selection process (Barabarosog lu and Yazgac, 1997; Weber et al., 1998; Ghodsypour and O'Brien, 1998; Deagraeve et al., 2000; Tam and Tummala, 2001; Talluri and Narasimhan, 2003; Zhu, 2004).

\section{SUPPLIERS MANAGEMENT IN MINING SYSTEMS}

Expansion of global requires in mining has caused by advancements in of mining techniques, i.e. machinery and equipment, and their maintenance. It is generally accepted that modern mining systems require careful and detailed planning and control of all relevant technical, technological and other processes. For the smooth functioning of any production process, it is necessary to promptly provide adequate raw materials, spare parts, appropriate equipment, etc. However, it is not easy to provide all those things with the appropriate quality, adequate prices, terms of delivery. All this is followed by the risk at some stage, and that made a need for research in order to find optimal solutions in terms of selection of potentially reliable suppliers. Bearing in mind that the process of identifying and choice of reliable suppliers is a hard task, it is necessary to bring about the responsible and timely approach to this problem (Xia and $\mathrm{Wu}, 2007)$.

According to De Boer et al. (2001), the supplier selection process has various phases, such as defining the problem, making the formulation of criteria, identification of potential suppliers and making the final choice. The quality of the final selection largely depends on the quality of all steps involved in the selection process. Due to the shorter product life cycle, the search for new suppliers is a continuous priority for enterprises to improve the diversity and typology of their product range. Decision-makers are faced with a wide range of retail situations that lead to different decisions (Aissaoui et al., 2007).

So, the first step in the process of suppliers selecting is the determination of the final issues and knowledge of what we want to achieve by selection of suppliers. The suppliers selection is a very difficult task for managers, because the performance of suppliers ranging from criteria to criteria (Liu and Hai, 2005). Since the requirements for process of ore deposits exploiting are always uncertain, companies tend to manage their suppliers in different ways, leading to the development of supplier-supplier, vendor evaluation, 
vendor selection, vendor associations, coordination of suppliers, etc. (Chan, 2003). Strategic assessment of suppliers includes consideration of the practice of suppliers (Managerial, quality and finance, etc.) and the possibility of the supplier (co-design capabilities, the ability to reduce costs, technical skills, etc.) (Talluri and Narasimhan, 2003; Ertuğrul and Karakaşoğlu, 2008).

By management of suppliers, mining companies achieve a competitive advantage, reduce operating costs, shorten the delivery time of equipment, improved servicing of equipment, etc. In this way, mining companies increase the reliability of work with the final objective of making a profit and survival in the market. So, companies need to select the best suppliers and build long-term and profitable relationships with them in order to achieve growth and prosperity in today's global competitive market.

\section{FUZZY TOPSIS METHOD}

TOPSIS method defines the ideal and anti-ideal solution. The ranking of alternatives is based on "relative similarity to ideal solution" and thus avoiding possible case of simultaneous similarities the alternative with ideal and negative ideal solution. In this method, the weights of attributes and evaluation of alternatives are accurately known and crisp values that are used in the evaluation process. However, the use of crisp values is one of the problematic points in the evaluation process as precise information is not adequate to create decision problems model in real life. Therefore, we suggest using Fuzzy TOPSIS method, in which the weight of the criteria and the assessment of alternatives are evaluated by linguistic variables that are represented by fuzzy numbers and thus overcomes the aforementioned disadvantage.

According to Ertuğrul and Karakaşoğlu (2008), Fuzzy TOPSIS method can be presented in several steps as follows:

Step 1. Forming a set of decision-makers, which consists of $\mathrm{K}$ decision-makers where fuzzy evaluation for each decision-maker $\mathrm{D}_{k}, k=1,2, . ., K$ can be displayed as a triangular fuzzy number $\widetilde{R k}, k=1,2, \ldots, K$ with the membership function $\mu \widetilde{R k}_{(x)}$.

Step 2. Determination of criteria for the evaluation, selection appropriate linguistic variables for the evaluation criteria and alternatives, and aggregation of the criteria weights for evaluation. If the fuzzy number for evaluation of all decision-makers is described by the triangular fuzzy numbers $\widetilde{R_{k}}\left(\mathrm{a}_{\mathrm{k}}, \mathrm{b}_{\mathrm{k}}, \mathrm{c}_{\mathrm{k}}\right), k=1,2, \ldots, K$, then the aggregate fuzzy evaluation may be represented by $\tilde{R}(a, b, c), k=1,2, \ldots, K$, using the expression $a=\min _{k}\left\{a_{k}\right\}, b=\frac{1}{k} \sum_{k=1}^{k} b_{k}, c=\max _{k}\left\{c_{k}\right\}$. If the fuzzy evaluation $\tilde{x}_{i j k}\left(a_{i j k}, b_{i j k}, c_{i j k}\right)$, the importance of weight for the $k$-th decision-maker $\tilde{x}_{i j k}\left(a_{i j k}, b_{i j k}, c_{i j k}\right), i=1,2, \ldots, m ; j=1,2, \ldots, n$, then the aggregate fuzzy evaluation $\left(\tilde{x}_{i j k}\right)$ of alternatives to each criterion can be defined as $\tilde{x}_{i j k}\left(a_{i j k}, b_{i j k}, c_{i j k}\right)$, where je $a_{i j}=\min _{k}\left\{a_{i j k}\right\}, b_{i j}=\frac{1}{k} \sum_{k=1}^{k} b_{i j k}, c_{i j}=\max _{k}\left\{c_{i j k}\right\}$. 
Step 3. For each criteria the calculation of the aggregated fuzzy weight $\left(\widetilde{w}_{i j}\right)$, as $\left(\widetilde{w}_{j l}\right)$ $=\left(\widetilde{w}_{j 1}, \widetilde{w}_{j 2}, \widetilde{w}_{j 3}\right)$, where $\widetilde{w}_{j l}=\min _{k}\left\{\widetilde{w}_{j k 1}\right\}, \widetilde{w}_{j 2}=\min _{k}\left\{\widetilde{w}_{j k 2}\right\}, \widetilde{w}_{j 3}=\min _{k}\left\{\widetilde{w}_{j k 3}\right\}$ is carried out.

Step 4. Creation of fuzzy decision matrix and calculation of criteria weight, as $W=\left(w_{1}\right.$, $\left.w_{2}, w_{3}\right)$, where $\left(\tilde{X}_{i j}\right)=\left(\tilde{a}_{i j}, \tilde{b}_{i j}, \tilde{c}_{i j}\right) \mathrm{I}\left(\widetilde{w}_{i j}\right)=\left(\widetilde{w}_{j 1}, \widetilde{w}_{j 2}, \widetilde{w}_{j 3}\right), i=1,2, . ., m ; j=1,2, \ldots, n$, are approximated with positive triangular numbers.

Step 5. After creating a decision matrix, a normalization of the matrix is performing using a linear scale for transformation. The calculation is carried out as follows:

$$
\tilde{n}_{i j}=\frac{\tilde{x}_{i j}}{\sqrt{\sum_{i=1}^{m} \tilde{x}_{i j}^{2}}} i=1, \ldots, m, j=1, \ldots, n
$$

Step 6. In this step the „aggregated“ (weighted) normalized fuzzy decision matrix is created. Normalized weighted value of the matrix $\tilde{v} \mathrm{ij}$ is calculated by the following formula:

$$
\tilde{v}_{i j}=\widetilde{w}_{j} \tilde{n}_{i j} i=1, \ldots, m, j=1, \ldots, n
$$

Step 7. Calculation of the fuzzy positive ideal solutions (FPIS, $A^{*}$ ) and the fuzzy negative ideal solution (FNIS, A- ) is realized by using the following expressions:

$$
\begin{aligned}
& \mathrm{A}^{*}=\left\{\tilde{v}_{1}^{*}, \tilde{v}_{2, \ldots}^{*}, \tilde{v}_{\mathrm{i}}^{*}\right\}=\left\{\left(\max _{\mathrm{j}} \tilde{v}_{\mathrm{ij}} \mid \mathrm{i} \in \mathrm{I}^{\prime}\right),\left(\min _{\mathrm{j}} \tilde{\mathrm{v}}_{\mathrm{j}} \mid \mathrm{i} \in \mathrm{I}^{\prime \prime}\right), \mathrm{i}=1,2, \ldots, \mathrm{n} ; \mathrm{j}=1,2, \ldots, \mathrm{J},\right. \\
& \mathrm{A}^{-}=\left\{\tilde{v}_{1}^{-}, \tilde{v}^{-}, \ldots, \tilde{v}_{\mathrm{i}}\right\}=\left\{\left(\min _{\mathrm{j}} \tilde{v}_{\mathrm{i} j} \mid \mathrm{i} \in \mathrm{I}^{\prime}\right),\left(\max _{\mathrm{j}} \tilde{v}_{\mathrm{ij}} \mid \mathrm{i} \in \mathrm{I}^{\prime \prime}\right), \mathrm{i}=1,2, \ldots, \mathrm{n} ; \mathrm{j}=1,2, \ldots, \mathrm{J} .\right.
\end{aligned}
$$

Step 8. Calculation of the distance of each alternative from the calculated FPIS and FNIS is done using the following expressions:

$$
D_{j}^{*}=\sqrt{\sum_{j=1}^{n}\left(\tilde{v} \mathrm{ij}-\tilde{v}_{i}^{*}\right)^{2}}, \quad j=1,2, \ldots, J
$$




$$
D_{j}^{-}=\sqrt{\sum_{j=1}^{n}\left(\tilde{v} \mathrm{ij}-\tilde{v}_{i}^{-}\right)^{2}}, \quad j=1,2, \ldots, J
$$

Step 9. Calculation of similarities according to the ideal solution is carried out as follows:

$$
\mathrm{CC}_{\mathrm{j}}=\frac{D j^{-}}{D j^{*}+D j^{-}}, \quad j=1,2, \ldots, \mathrm{J} .
$$

whereby the $i \mathrm{CC} j$ with their values belong to the closed interval $[0,1]$.

Step 10. The ranking of alternatives is made by taking into account the value of the $i$ $\mathrm{CC} j$ where is on the first place the alternative with the maximum value of $i \mathrm{CC} j$.

\section{RESULTS OF FUZZY TOPSIS METHOD}

In this paper the multi-criteria analysis method (Fuzzy TOPSIS) is used for the purpose of selecting the best suppliers operating in mining systems in the Public Company for Underground Coal Mining Resavica (JPPEU Resavica) - Serbia. Ranking of companies is done based on ten criteria (management and organization, quality, technical ability, production facilities and capacity, financial position, delivery, service, relationshipconnectivity, security and environmental protection and price), and has considered a list of five suppliers (Supplier 1; Supplier 2; Supplier 3; Supplier 4; Supplier 5). The experts knowledge from JPPEU Resavica is used to determine the significance and impact of certain criteria to the process of supplier selection and evaluation of suppliers in regard to each criterion - Table 2 .

Based on the values of linguistic variables (Figure 1, Table 1), a fuzzy decision matrix for the selection of suppliers was formed. This matrix is presented in the upper part of Table 3, while in the lower part of the table, the fuzzy numbers that are the equivalent of linguistic variables are shown. 
Table 1 The linguistic importance scale

\begin{tabular}{cc}
\hline The linguistic evaluation scale & Triangular fuzzy scale \\
Very low -VL & $(0.00,0.10,0.25)$ \\
Ledium- M & $(0.15,0.30,0.45)$ \\
High-H & $(0.35,0.50,0.75)$ \\
Very High-VH & $(0.55,0.70,0.85)$ \\
\hline
\end{tabular}

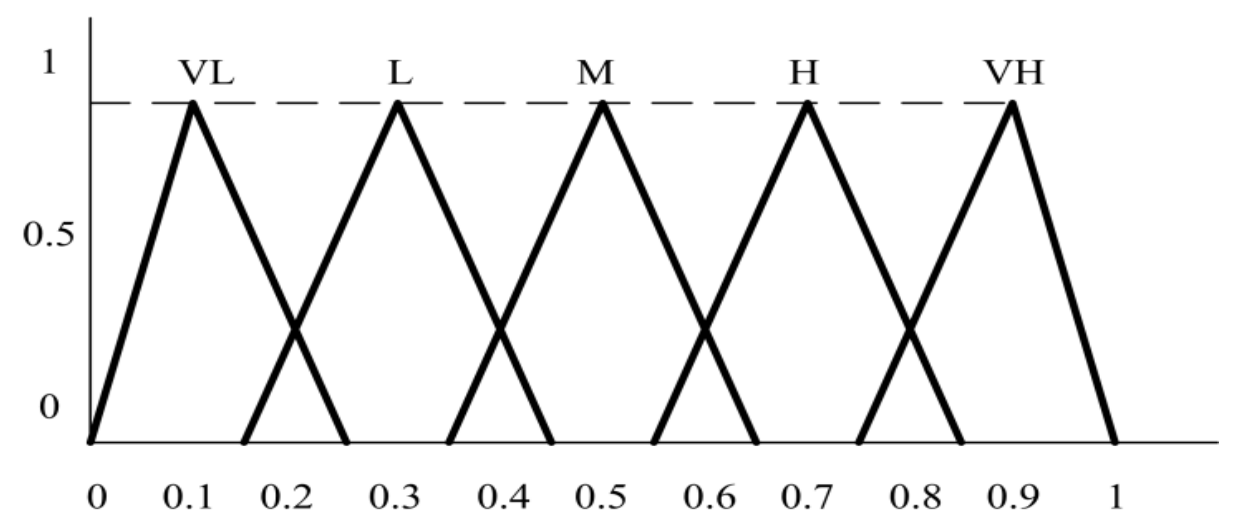

Figure 1 The linguistic evaluation scale 
Suppliers ranking in production system by fuzzy TOPSIS method...

Table 2 The values of criteria weights obtained from expers, as well as their mean

\begin{tabular}{|c|c|c|c|c|c|c|c|c|c|c|c|}
\hline $\begin{array}{l}\text { Expert } \\
\text { Criteria }\end{array}$ & 1 & 2 & 3 & 4 & 5 & 6 & 7 & 8 & 9 & 10 & $\begin{array}{l}\text { Arithmetic } \\
\text { mean }\end{array}$ \\
\hline Management & & & & & & & & & & & \\
\hline $\begin{array}{l}\text { and organization } \\
\text { (M) }\end{array}$ & 0,07 & 0,08 & 0,10 & 0,05 & 0,05 & 0,07 & 0,05 & 0,09 & 0,02 & 0,13 & 0,07 \\
\hline Quality (K) & 0,28 & 0,22 & 0,20 & 0,20 & 0,30 & 0,15 & 0,10 & 0,20 & 0,35 & 0,20 & 0,22 \\
\hline Tech. ability (T) & 0,02 & 0,03 & 0,10 & 0,05 & 0,05 & 0,06 & 0,06 & 0,05 & 0,02 & 0,08 & 0,05 \\
\hline Production & & & & & & & & & & & \\
\hline $\begin{array}{l}\text { facilities and } \\
\text { capacity (P) }\end{array}$ & 0,03 & 0,04 & 0,04 & 0,05 & 0,10 & 0,04 & 0,03 & 0,11 & 0,03 & 0,05 & 0,05 \\
\hline $\begin{array}{l}\text { Financial } \\
\text { position (F) }\end{array}$ & 0,13 & 0,14 & 0,10 & 0,20 & 0,01 & 0,02 & 0,02 & 0,09 & 0,10 & 0,08 & 0,10 \\
\hline Delivery (I) & 0,08 & 0,10 & 0,15 & 0,10 & 0,05 & 0,15 & 0,10 & 0,10 & 0,13 & 0,07 & 0,10 \\
\hline Service (S) & 0,07 & 0,09 & 0,03 & 0,05 & 0,05 & 0,10 & 0,15 & 0,10 & 0,05 & 0,10 & 0,08 \\
\hline $\begin{array}{l}\text { Relationship- } \\
\text { connectivity (O) }\end{array}$ & 0,06 & 0,04 & 0,03 & 0,05 & 0,05 & 0,04 & 0,04 & 0,04 & 0,03 & 0,04 & 0,04 \\
\hline $\begin{array}{l}\text { Security and } \\
\text { environmental } \\
\text { protection (B) }\end{array}$ & 0,04 & 0,05 & 0,05 & 0,05 & 0,05 & 0,12 & 0,18 & 0,02 & 0,02 & 0,04 & 0,06 \\
\hline Price (C) & 0,22 & 0,21 & 0,20 & 0,20 & 0,20 & 0,25 & 0,27 & 0,20 & 0,25 & 0,21 & 0,22 \\
\hline$\Sigma$ & 1 & 1 & 1 & 1 & 1 & 1 & 1 & 1 & 1 & 1 & \\
\hline
\end{tabular}

After determining the fuzzy decision matrix, the next step is weighting the normalized value of the matrix $\tilde{v} \mathrm{ij}$, based on the criteria weight, calculated by AHP method (Table 2 ) and formula (2). The resulting weighted fuzzy decision matrix is shown in Table 4. 


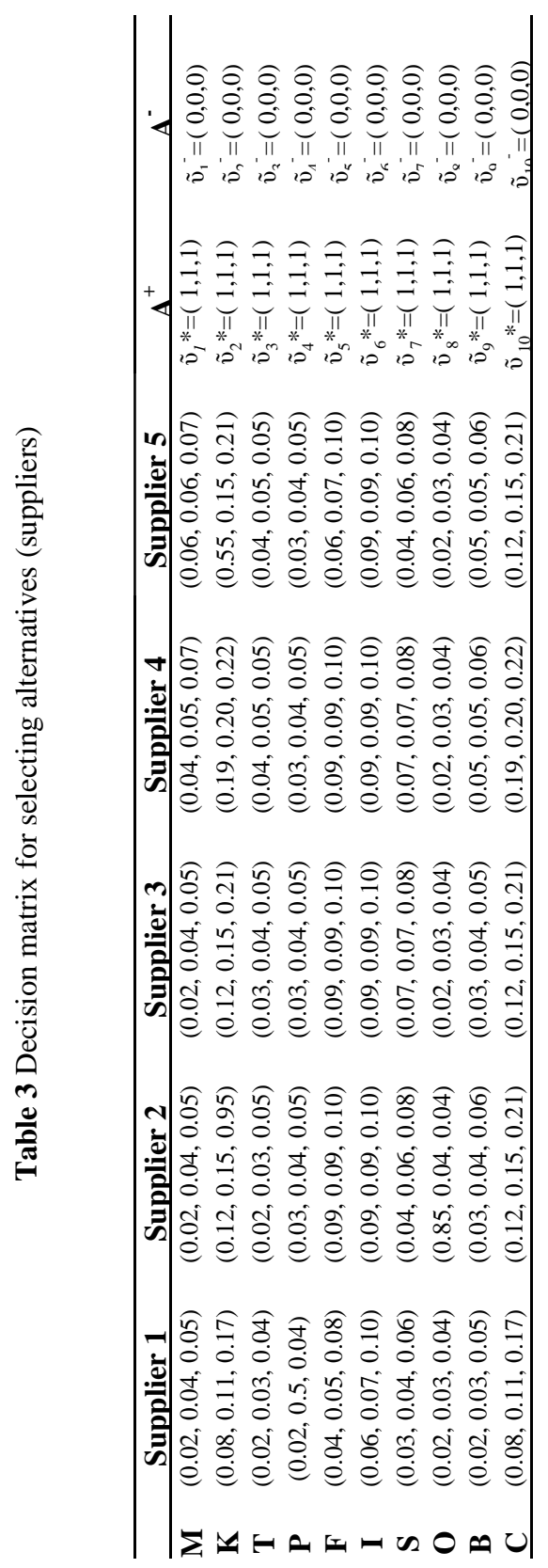




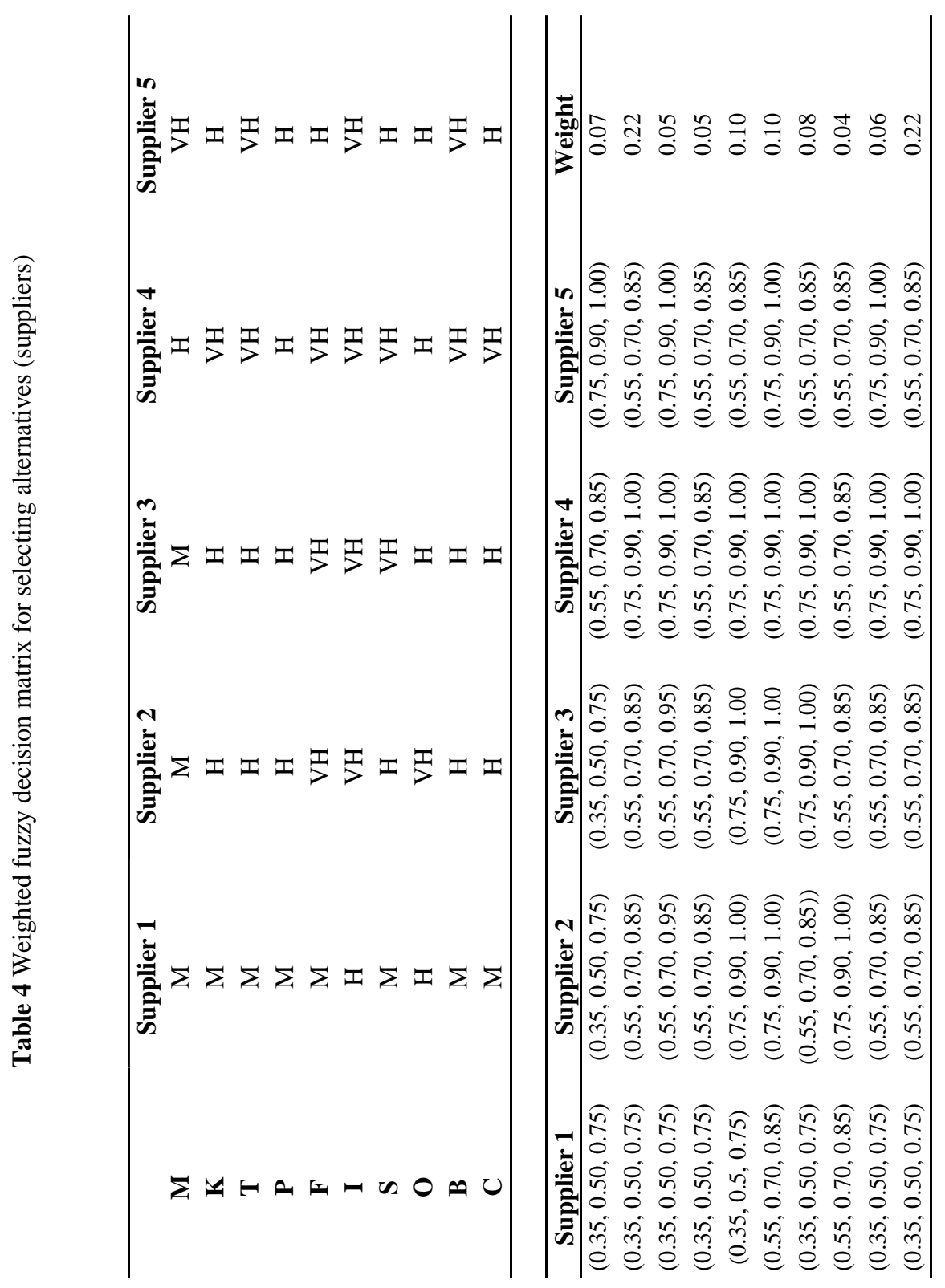

Table 4 shows that $\tilde{\mathrm{v}} \mathrm{ij}$ are the elements normalized positive triangular fuzzy numbers and their ranges are within the interval $[0,1]$. In this way, the fuzzy positive ideal solution (FPIS A *) and the fuzzy negative ideal solution (FNISA-) can be defined. The same calculations are done for other alternatives. The results of the fuzzy TOPSIS analysis are shown in Table 5. 
Table 5 The results of the Fuzzy Topsis analysis

\begin{tabular}{ccccc}
\hline & D+ & D- & CCj & RANK \\
\hline D1 & 9.428776 & 0.596012 & 0.0595 & 5 \\
D2 & 9.250326 & 0.763427 & 0.0762 & 3 \\
D3 & 9.256157 & 0.759534 & 0.0758 & 4 \\
D4 & 9.231444 & 0.781158 & 0.0780 & $\mathbf{1}$ \\
D5 & 9.252346 & 0.763879 & 0.0763 & 2 \\
\hline
\end{tabular}

The analysis of the results of this model leads to the conclusion that the best alternative is supplier D4, with a value of similarity to ideal solution $\mathrm{CCj}=0.0780$. In the second place is supplier $\mathrm{D} 5$, with $\mathrm{CCj}=0.0763$, on the third place is supplier $\mathrm{D} 2$, with $\mathrm{CCj}=0.0762$, on the fourth place is supplier $\mathrm{D} 3$, with $\mathrm{CCj}=0.0758$ and the last is supplier $\mathrm{D} 1$, with $\mathrm{CCj}=0.0595$.

\section{CONCLUSION}

In most activities, the price of raw materials and components makes for the largest percentage of total production costs. In high-tech companies, procurement of materials and services make up to $80 \%$ of total product costs. Therefore, it can be said that the selection of the right suppliers is a key procurement process, as well as a great opportunity for companies.

Choosing the right method for selecting a supplier effectively leads to a reduction in purchasing risk and increases the number of suppliers "at the right time" (JIT). The issues of supplier selection have attracted the interest of many researchers since the 1960s, and research studies in this area have increased significantly. A large number of authors pointed to the importance of choosing a supplier emphasizing the impact that these decisions have on the whole supply chain, starting from purchasing raw materials to delivering finished products to the customers.

Bearing in mind the strategic significance of suppliers' role in the functioning of the supply chain, researchers have developed a variety of criteria, methods and models for the selection of suppliers. In this paper was performed Fuzzy TOPSIS multi-criteria method for ranking suppliers in JPPEU Resavica. The selection of the best suppliers in each necessary business segment is one of the most important decisions that every company has to make. The selection process requires consideration of a numerous criteria related to the quality of goods and services, their price, the financial position of the supplier, delivery and others. Selecting the best companies is done on the basis of a comparison of all the interested suppliers in accordance with appropriate criteria. 
The paper considers 10 criteria that have the greatest impact on the evaluation and ranking of suppliers and 5 suppliers that have been analyzed and assessed in terms of defined criteria.

Accordingly, it is used the Fuzzy TOPSIS method for obtaining the final rank of suppliers. This method used the expert knowledge from organization JPPEU Resavica. Experts independently and individually evaluated the weights of all criteria in the first phase, and in the second phase they have evaluated suppliers using marks from 1 to 5 with respect to all criteria. Thereafter, it is calculated average values of criteria weights and supplier marks. The obtained data were used for the final ranking of suppliers by Fuzzy TOPSIS method.

Based on obtained results, the best ranking is supplier 4 while other suppliers are ranked in the following order: Supplier 5, Supplier 2, Supplier 3 and Supplier 1.

The obtained results show that the application of fuzzy TOPSSIS method in a mining business environment is of great importance, which was one of the goal of this paper.

This method of ranking that relies mostly on the expert knowledge of managers that are users of goods and services provided by suppliers has great advantages over other methods because it provides the maximum certainty, objectivity and accuracy of the results.

\section{ACKNOWLEDGMENTS}

The research presented in this paper was done with the financial support of the Ministry of Education, Science and Technological Development of the Republic of Serbia, within the funding of the scientific research work at the University of Belgrade, Technical Faculty in Bor, according to the contract with registration number 451-03-9/2021-14/ 200131.

\section{REFERENCES}

AHN, G. and HUR, S. (2016) Markov network model with unreliable edges. International Journal of Industrial Engineering, 23(3), pp. 174-182.

AISSAOUI, N., HAOUARI, M. and HASSINI, E. (2007) Supplier selection and order lot sizing modeling. Computers \& Operations Research, 34, pp. 3516-3540.

BAI, C. and SARKIS, J. (2010) Integrating sustainability into supplier selection with grey system and rough set methodologies. International Journal Production Economic, 124, pp. 252-264.

BARABAROSOG ${ }^{\complement} \mathrm{LU}, \mathrm{G}$. and YAZGAC, T. (1997) An application of the analytic hierarchy process to the supplier selection problem, Production and Inventory Management Journal, pp. 14-21. 
BIRCH, D. (2001) Corporate citizenship, rethinking business beyond corporate social responsibility. J. Andriof and M. McIntosh (eds.) Perspectives on corporate citizenship. London: Greenleaf Publishing. pp. 53-65.

CELEBI, D. and BAYRAKTAR D. (2008) An integrated neural network and data envelopment analysis for supplier evaluation under incomplete information, Expert Systems with Applications, 35 (4), pp. 1698-1710.

CHAN, F. T. S. (2003) Interactive selection model for supplier selection process: An analytical hierarchy process approach. International Journal of Production Research, 41, pp. 3549-3579.

CHEN, C. T., LIN, C. T. and HUANG, S. F. (2006) A fuzzy approach for supplier evaluation and selection in supply chain management. International Journal of Production Economics, 102, pp. 289-301.

CHOY, K. L. and LEE, W. B. (2002) A generic tool for the selection and management of supplier relationships in an outsourced manufacturing environment: the application of case based reasoning. Logistic Information Management, 15, pp. 235-253.

CROOM, S. (2001) The dyadic capabilities concept: examining the processes of key supplier involvement in collaborative product development. European Journal of Purchasing and Supply Management, 7, pp. 29-37.

DE BOER, L., LABRO E. and MORLACCHI, P. (2001) A review of methods supporting supplier selection. European Journal Purch Supply Management, 7, pp. 7589.

DEAGRAEVE, Z., LABRO, E. and ROODHOOFT, F. (2000) An evaluation of vendor selection models from a total cost of ownership perspective. European Journal of Operational Research, 125, pp. 34-58.

DICKSON, G. (1966) An analysis of vendor selection systems and decisions. Journal of Purchasing, 2, pp. 5-17.

EKICI, A. (2013) An improved model for supplier selection under capacity constraint and multiple criteria. International Journal Production Economic, 141, pp. 574-581.

ELLRAM L. (1990) The supplier selection decision in strategic partnerships. Journal of Purchasing and Material Management, 26(1), pp. 8-14.

ERHARDT, G., LANGLINAIS, T. and RATTA, V. (2010) The call to become customer smart. Technical Report Accenture.

ERTUĞRUL, İ. and KARAKAŞOĞLU, N. (2008) Comparison of fuzzy AHP and fuzzy TOPSIS methods for facility location selection, The International Journal of Advanced Manufacturing Technology, 39(7-8), pp. 783-795. 
EVANS, R. H. (1980) Choice criteria revisited. Journal of Marketing, 44(1), pp. 55-56.

GHODSYPOUR, S. H. and O'BRIEN C. (1998) A decision support system for supplier selection using an integrated analytic hierarchy process and linear programming. International Journal of Production Economics, 56-57, pp. 199-212.

KAR, A. K. and PANI, A. K. (2014) How can a group of procurement experts select suppliers? An approach for group decision support. Journal of Enterprise Information Management, 27(4), pp. 337-357.

KUMAR, M., VRAT, P. and SHANKAR, R. (2006) A fuzzy programming approach for vendor selection problem in a supply chain. International Journal of Production Economics, 101, pp. 273-285.

LEE, J., CHO, H. and KIM, Y. S. (2014) Assessing business impacts of agility criterion and order allocation strategy in multi-criteria supplier selection. Expert Systems with Applications, 42(3), pp. 1136-1148.

LEHMANN, D. R. and O'SHAUGHNESSY, J. (1974) Difference in attribute importance for different industrial products. Journal of Marketing, 38(2), pp. 36-42.

LEWIS, W. A. (1943) Monopoly and the law. An economist's reflections on the Crofter case. The Modern Law Review, 4(3), pp. 97-111.

LI, C. C. and FUN, Y. P. (1997) A new measure for supplier performance evaluation. IIE Transactions, 29(1), pp. 753-758.

LIMA, F. R., OSIRO, L. and CARPINETTI, L. C. R. (2013) A fuzzy inference and categorization approach for supplier selection using compensatory and noncompensatory decision rules. Applied Soft Computing, 13, pp. 4133-4147.

LIN, H. T. and CHANG, W. L. (2008) Order selection and pricing methods using flexible quantity and fuzzy approach for buyer evaluation. European Journal of Operational Research, 187(2), pp. 415-428.

LIN, R. H. (2012) An integrated model for supplier selection under a fuzzy situation. International Journal of Production Economics, 138, pp. 55-61.

LIU, F. H. F. and HAI, H. L. (2005) The voting analytic hierarchy process method for selecting supplier. International Journal of Production Economics, 97, pp. 308-317.

MAFAKHERI, F., BRETON, M. and GHONIEM, A. (2011) Supplier selection order allocation: a two stage multiple criteria dynamic programming approach. International Journal of Production Economics, 132, pp. 52-57.

MEDINI, K. (2015) Modularity and variety spinoffs: a supply chain planning perspective. International Journal of Industrial Engineering, 22(6), pp. 753-768. 
MENDOZA, A., SANTIAGO, E and, RAVINDRAN, A. R. (2008). A three-phase multicriteria method to the supplier selection problem, International Journal of Industrial Engineering: Theory, Applications and Practice, 15 (2), pp. 195-210

MIEMCZYK, J., JOHNSEN, T. E. and MACQUET, M. (2012) Sustainable purchasing and supply management: a structured literature review of definitions and measures at the dyad, chain and net work levels. Supply Chain Management, 17, pp. 478-496.

MURALIDHARAN, C., ANANTHARAMAN, N. and DESHMUKH, S. G. (2002) A multi-criteria group decision-making model for supplier rating. Journal of Supply Chain Management, 38, pp. 22-33.

PRAHINSKI, C. and BENTON, W. C. (2004) Supplier evaluations: communication strategies to improve supplier performance. Journal of Operations Management, 22, pp. $39-62$.

QIAN, L. (2014) Market-based supplier selection with price, delivery time, and service level dependent demand. International Journal of Production Economics, 147, pp. 697 706.

SHIN, H., COLLIER, D. A. and WILSON, D. D. (2000) Supplier management orientations and supplier/buyer performance. Journal of Operations Management, 18, pp. 317-333.

SHIPLEY, D. D. (1985) Reseller's supplier selection criteria for different consumer products. European Journal of Marketing, 19, pp. 26-36.

STOJANOVIĆ, S. G. (2016) Razvoj hibridnog višekriterijumskog modela u fazi okruženju za prioritizaciju pouzdanosti dobavljača u rudarskim sistemima. (PhD), Belgrade University-Technical faculty in Bor.

TALLURI, S. and NARASIMHAN, R. (2004) A methodology for strategic sourcing. European Journal of Operational Research, 154, pp. 236-250.

TALLURI, S. and NARASIMHAN, R. (2003). Vendor evaluation with performance variability: a max-min approach, European Journal of Operational Research, 146, pp. $543-552$.

TAM, M. C. Y. and TUMMALAV, M. R. (2001) An application of the AHP in vendor selection of a telecommunications system. OMEGA - The International Journal of Management Science, 29, pp. 171-182.

VANTEDDU, G., CHINNAM, R. B. and GUSHIKIN, O. (2011) Supply chain focus dependent supplier selection problem. International Journal of Production Economics, 129, pp. 204-216. 
VERMA, R. and PULLMAN, M. E. (1998) An Analysis of the Supplier Selection Process. OMEGA - The International Journal of Management Science, 26, pp. 739-750.

VOKURKA, R. J., CHOOBINEH, J. and VADI, L. (1996) A prototype expert system for the evaluation and selection of potential suppliers. International Journal of Operations and Production Management, 16, pp. 106-127.

WANG, J. W., CHENG, C. H. and CHENG, H. K. (2009) Fuzzy hierarchical TOPSIS for supplier selection. Applied Soft Computing, 9, pp. 377-386.

WEBER, C. L., CURRENT, J. R. and BENTON, W. C. (1991) Vendor selection criteria and methods. European Journal of Operational Research, 50, pp. 2-18.

WEBER, C. H., CURRENT, J. R. and DESAI, A. (1998) Non-cooperative negotiation strategies for vendor selection, European Journal of Operational Research, 108, pp. 208-223.

WU, D. and OLSON, D. L. (2008) Supply chain risk, simulation, and vendor selection. International Journal of Production Economics, 114, pp. 646-655.

XIA, W. and WU, Z. (2007) Supplier selection with multiple criteria in volume discount environments. Omega, 35, pp. 494-504.

ZEYDAN, M., ÇOLPAN, C. and ÇOBANOGLU, C. (2011) A combined methodology for supplier selection and performance evaluation. Expert Systems with Applications, 38, pp. 2741-2751.

ZHU, J. (2004) A buyer-seller game model for selection and negotiation of purchasing bids: extensions and new models, European Journal of Operational Research, 134, pp. $150-156$. 